\title{
BMJ Open Organisational participation and health among smallholder farmers: a longitudinal study in a Latin American context
}

\author{
Fadya Orozco, ${ }^{1}$ Eduardo Mota, ${ }^{2}$ Donald C Cole ${ }^{3}$
}

To cite: Orozco F, Mota E, Cole DC. Organisational participation and health among smallholder farmers: a longitudinal study in a Latin American context. BMJ Open 2014;4:e004641.

doi:10.1136/bmjopen-2013004641

- Prepublication history for this paper is available online. To view these files please visit the journal online (http://dx.doi.org/10.1136/ bmjopen-2013-004641).

Received 10 December 2013 Revised 29 September 2013 Accepted 1 October 2014

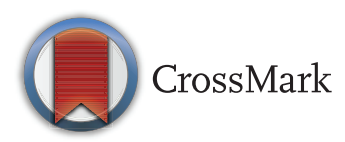

${ }^{1}$ Universidad San Francisco de Quito, Colegio de Ciencias de la Salud, Escuela de Salud Pública, Cumbaya-Quito, Pichincha, Ecuador ${ }^{2}$ Instituto de Saúde Coletiva, Universidade Federal da Bahia, Salvador de Bahia, Brazil

${ }^{3}$ Dalla Lana School of Public Health, University of Toronto, Toronto, Ontario, Canada

\footnotetext{
${ }^{*}$ Correspondence to Dr Fadya Orozco; forozco@usfq.edu.ec, fady50@yahoo.es
}

\section{ABSTRACT}

Objective: To understand the impact of social organisation affiliation and farmers' agricultural production practices on farmer health. Organisations facilitate the acquisition and exchange of forms of social capital which can influence the adoption of practices with potential health impacts. In countries such as Ecuador, smallholder agriculture is practised by socially vulnerable populations. Agricultural production often involves the use of extremely hazardous pesticides, while practices that reduce the use of chemicals through integrated pest management (IPM) remain uncommon.

Design: Longitudinal study (2007-2010).

Setting: 12 Ecuadorian communities, previously part of a participatory action research study.

Participants: 208 small-scale farmers. Inclusion criteria were: age between 18 and 65 years, literate and resident in the community for the previous 3 years.

Primary outcomes: The differential effects of the membership in social organisations (as an effect modifier), on the relationship between the implementation of IPM practices (main independent variable) and farmers' health, measured by neurocognitive performance scores (better higher value; dependent variable).

Results: Among organisational participants, the coefficient of association between the implementation of IPM practices for the category good/very good (vs no use) and neurocognitive performance, when farmers were involved in organisations, was negative and moderate $(\beta=-0.17$, SE 0.21$)$ though not significant $(p>0.1)$; for the category little/moderate use, the coefficient was positive $(\beta=0.34$, SE 0.19$)$ and significant. Among those who did not participate in organisations, both little/moderate use and good/very good use of IPM practices were associated with an increase in neurocognitive performance.

Conclusions: The effect of agricultural production practices on farmers' health, transmitted through organisations, can be differentiated. Organisations as structures of social capital seem to be functional in the social reproduction process of the communities studied. Results highlight the need to redirect the analysis of social capital to a more integrated study of social determination of health.

\section{Strengths and limitations of this study}

- In a context of social inequality, we sought to understand the role of forms of social capital, transmitted through organisations, on agricultural production processes and farmer health.

- We used a longitudinal study design in vulnerable communities sharing livelihood strategies and agricultural production processes.

- The studied communities had previously participated in interventions which provided information about the links between health and agriculture, potentially decreasing the study's generalisability.

\section{INTRODUCTION}

Organisations are social structures that enable the acquisition and exchange of information that can affect the adoption of practices that have potential health impacts. ${ }^{1}{ }^{2}$ Theoretically, organisations and highly cohesive networks are social structures that facilitate different forms through which social capital is promoted and developed. ${ }^{3}$ These forms include norms and values, obligations and expectations, and information exchange. ${ }^{3}$ Similarly, social capital allows actors within these structures to achieve certain objectives that otherwise would be difficult to achieve. ${ }^{3}$ Social capital is a multidimensional concept ${ }^{13}$; therefore, treating it as a combination of structures and forms ${ }^{4}$ can facilitate an understanding of the effects of social capital on population health and well-being.

In recent years, some authors ${ }^{5-13}$ have questioned the applicability of the concept of social capital, whose roots lie in the fields of economics and sociology. ${ }^{3}{ }^{14}$ Social capital as a determinant of psychosocial health has been the focus of analysis. ${ }^{115-17}$ The primary limitation of this approach is its analytical disconnect from the determinants of health 
inequity, such as social class and power relations, which underlie psychosocial determination. ${ }^{5}{ }^{6}$ It is important to understand social capital in a broader context, as a social determinant of health, which is in turn defined by other determinants. From Bourdieu's perspective, ${ }^{14}$ social capital exists and has effects within the context in which it is produced and reproduced. This context depends on the political, historical, economic and cultural environments of adjacent contexts ${ }^{5-10} 18$ within an ecological view of the social determinants of health.

In middle-income countries such as Ecuador, smallholder agricultural production focuses on consumption and on supplying the domestic market with staples. This production is developed as a family activity in ethnically homogeneous and highly cohesive rural farming communities. ${ }^{2}$ In much smallholder farming, the market production model focuses on potato monoculture on land ranging in size from 0.2 to 5 hectares. ${ }^{19}$ The levels of economic capital investment in this type of farming are low, and heavily dependent on labour and the use of inexpensive and highly toxic chemical treatments. ${ }^{20}$ As a result, economic return is also low, with a monthly average per family of approximately US $\$ 340 .^{21}$ This income can fluctuate depending on domestic market conditions, which depend on external market and climatic conditions. Owing to these limitations, smallholder agriculture is an economic activity with high uncertainties. Therefore, the population whose livelihood revolves around that activity is in a position of social vulnerability. ${ }^{19} 2223$

With the objective of understanding the dynamics of social capital within the context of development, we implemented a prior longitudinal study ${ }^{2}$ which explored the role of organisations, as social capital structures, in maintaining and transmitting health information related to agricultural production practices, taking into account farmers' livelihoods. Information was understood to be a form of social capital. ${ }^{3}$ The results suggested that information flow is facilitated based on the perceived value of information by rural communities. ${ }^{24}$ For example, organisations, regardless of their attributes or categories, were social structures that, over time, had facilitated the transfer of information about integrated pest management (IPM) practices. These practices aim to reduce the impact of agricultural externalities on the environment and on human health while maintaining farm productivity and profitability. ${ }^{25}$ IPM practices include reducing the use of pesticides, emphasising natural and cultural practices, and resorting to the use of (less toxic) pesticides only when necessary. ${ }^{26}$ The findings of our first study ${ }^{2}$ suggested that organisations' underlying values promoted health as a life resource which was necessary in the context of the extractive production model applied in small-scale agriculture. Recent studies ${ }^{45}$ have identified the need to understand what is facilitated by social structures, which can assist in the comprehension of the relationship between social capital and health impacts arising from a comprehensive view of the determinants of health.
Adopting the definition proposed by Bourdieu, ${ }^{14}$ social capital is a non-economical way to generate economic capital under certain conditions through institutionalised social networks. In this second article, we performed an analysis of agricultural production practices and organisational participation and their relationship to farmer health. The hypothesis of the present study was that the health impacts associated with the implementation of IPM practices could be differentiated according to farmers' participation in organisations. We attempt to understand the impacts on health associated with the practices transmitted through social structures, which are embedded in a community context of inequality and social vulnerability.

Both the current study and the first longitudinal study $^{2}$ were based on a prior intervention study developed in the context of a participatory action research project on health and agriculture (EcoSalud II) during 2005-2008 in the same population. ${ }^{27} 28$ The purpose of that project ${ }^{27} 28$ was to promote health as a resource for living among smallholder farmers through training in organic production approaches and education on human health effects related to the use of pesticides and, in particular, pesticides with greater toxicity. In this article, we analyse the role of participation in organisations as social capital structures, as an effect modifier, on the relationship between agricultural production practices and the health of smallholder farmers. We aimed to provide evidence to inform the growing debate on social capital under the paradigm of development in a middle-income country.

\section{METHODS}

\section{Study design, area and community selection}

The study design was longitudinal and incorporated repeated measures on the same group of individuals, the first (T1) conducted in July 2007 and the second in February 2010 (T2). The study was carried out in 12 agriculture communities in the neighbouring provinces of Chimborazo (5 communities) and Tungurahua ( 7 communities). All of the communities were engaged in smallholder commercial potato production. These communities (12) were part of an initial sample of 24 communities participating in a health and agriculture intervention project in 2005 (EcoSalud $\mathrm{II}) .^{27} 28$ Twenty-four communities were chosen using the following criteria: (1) potato production was very important; (2) smallholder farmers were predominant; and (3) strategic partners were present in the area to facilitate the development of activities related to agricultural interventions. Those partners specialised in agricultural technology transfer and emphasised alternative marketing processes.

In February 2007 (T1), 12 among the 24 communities were chosen for this study, primarily on the basis of their involvement in interventions carried out during EcoSalud II (for further details, see Orozco et $a l^{27}$ )- 
that is, good leadership support, substantial interest by community members, and the implementation of most of the agriculture and health interventions. Selected communities had medium to high intensities of implementation, through which existing social capital facilitated and maintained health information over time, thus being able to influence agricultural production practices, and associated health impacts.

\section{Participants and data collection}

Within each community, farm families were invited to participate in the study through community meetings. In July 2007, between 19 and 21 volunteer families in each community were interviewed. There were slight variations between communities depending on the availability of families from the initial study EcoSalud II (2005) at the later time (2007). The inclusion criteria for individual participants were defined in 2005 by the EcoSalud II project ${ }^{24}$ as follows: age between 18 and 65 years, literate, resident in the community for the previous 3 years, and interested in participating. An ethical review was conducted by the Bioethics Committee of the Ecuador National Health Council (T1) and the Internal Review Board of the Institute of Collective Health, Federal University of Bahia, Brazil (T2). The participants provided written, informed consent.

For each family, two questionnaires were used in structured interviews with the person in charge of farm management. The first questionnaire addressed crop management practices, for example, the use of pesticides and social capital, including the individual's participation in community organisations. The second questionnaire focused on the health-related effects of pesticide use. The questionnaires were based on previous studies conducted in Ecuador on a similar group of farmers. ${ }^{1922}{ }^{26}$ The questionnaires were pretested in the field to correct aspects related to verbal understanding and to ensure the interviewers' performance. Trained staff with professional skills in agronomy and health promotion conducted the interviews, directed by a field supervisor. In a few cases, additional visits were made when it was necessary to clarify and review incomplete or surprising information. During both periods, the person responsible for training the staff and managing the logistics of data collection was the first author of this article (FO). The duration of each data collection period was 1 month.

At T2, 213 of the initial 227 individuals originally interviewed at $\mathrm{T} 1$ were re-interviewed. The primary reason for loss was out-migration from the study area. Owing to the repeated-measure study design, complete data across both times were required, leaving a final sample of 208 individuals.

\section{Measures}

Data were entered into the CsPro2 software program and exported to STATA, V.9.0, for variable construction.
The dependent variable was neurocognitive performance, a measure of potential and/or actual physical or mental capacity. This choice was based on previous studies ${ }^{29}$ that found that ongoing exposure to pesticides contributed to decreased neurocognitive performance as measured by the 'Digit-Span' test. That test assesses short-term verbal memory, also referred to as working memory. The Digit-Span test forms part of a series of neurobehavioural tests recommended by the WHO to evaluate the effects of neurotoxic substances and has shown good reliability and validity. ${ }^{30}$ The procedure consisted of applying two subtests (forward and backward) for remembering and repeating a series of numbers provided orally by the interviewer. In each case, the maximum possible score value was 6 points. The scores from each subtest were added together and converted into a single value that ranged from 0 to 10 . Scores close to 0 reflected poor neurocognitive performance and greater impairment, whereas values close to 10 reflected better performance.

The principal independent variable was the use of IPM practices. We used a multiple-response question with a list of 16 possible IPM practices. For each practice, response options were as follows: 'does not know about it', 'knows about it,' and 'uses it.' For the last option, the frequency of use was also recorded as follows: never $(=0)$; sometimes $(=1)$; or always $(=2)$. Responses were summed to create a total score (ranging from 0 to 32), which was rescaled into an index (potentially ranging from 0 to 10). For analysis, the IPM use index was classified into tertiles found at $\mathrm{T} 1$ as follows: $0=$ does not use; $1=$ little or moderate use (ranging from 1.5 to 5); and 2=good/very good use (ranging from 5.3 to 8 ).

The key effect modifier of interest was organisational participation. The question 'Do you participate in any organization?' had options to answer no or yes, with the latter followed by the question 'In which organizations?' Responses of family members (primarily husbands and wives) were added to obtain a single score, which was attributed to each individual and recoded as follows: $0=$ no participation or $1=$ participation in at least one organisation. The answers to the open-ended question were classified into three categories: $1=$ agricultural organisations dedicated to potato production; $2=$ conflict-resolution organisations (water committees and fraternal organisations); and $3=$ others (credit, women's organisations, milk production and sports).

Another independent variable was Use of Pesticides Types Ib and II, classified by the $\mathrm{WHO}^{20}$ as being of high toxicity and moderate toxicity, respectively. Individuals were asked about the pesticides used in areas harvested over the previous 6 months, including the number of applications and the amount used per application. With active ingredients obtained for each commercial product and their respective toxicity ratings, the amounts of each pesticide type used were calculated in kilograms $(\mathrm{kg})$ per hectare (ha). In view of the asymmetry encountered in distributions, the quantities of Pesticides Ib and II 
were added and the sum was classified based on the first (0) and sixth deciles (1.1) as follows: $0=0 \mathrm{~kg} / \mathrm{ha} ; 1 \geq 0$ but $\leq 1.1 \mathrm{~kg} / \mathrm{ha}$; and $2 \geq 1.1 \mathrm{~kg} / \mathrm{ha}$. Covariates included were age and education (number of years of formal education) because previous studies have demonstrated their independent contribution to neurocognitive performance. $^{31}$

\section{Inferential analyses}

Significance was set at $10 \%$. Loss to follow-up was analysed using either $t$ tests or $\chi^{2}$ tests. Multivariable regression analyses were performed using generalised estimating equations, ${ }^{32} 33$ thus allowing effective estimates of parameters with correlated data. Longitudinal associations involved use of the variable time in the equation, ${ }^{32}$ dichotomised as $0=\mathrm{T} 1$ and $1=\mathrm{T} 2$. Confounding was assessed, the criterion being a change in the value of the coefficients $>10 \%$ with removal or addition of covariates.

To test the study hypothesis, three product terms (dummy variable) were created, ${ }^{34}$ based both on the existing literature ${ }^{18} 22$ and on preliminary Spearman correlation analyses: Term 1=Use of IPM practices good/ very good $\times$ organisational participation; Term 2=Use of IPM practices good/very good $\times$ use of Pesticides Ib and II $>1.1 \mathrm{~kg} / \mathrm{ha}$; and Term $3=$ Use of Pesticides Ib and II $>1.1 \mathrm{~kg} / \mathrm{ha} \times$ organisational participation.

We began multivariable modelling with a saturated model (A) that included all study variables and product terms. In the later models ( $\mathrm{B}, \mathrm{C}$ and $\mathrm{D})$, one product term was excluded at each stage. This technique was chosen to value the joint importance of the terms and later their individual significance $(p<0.1)$ within the model. ${ }^{35}$ The quasi-information criterion ' $\mathrm{QIC}_{\mathbf{u}}$ ' was one criterion for model selection, ${ }^{32}$ aiming for the lowest value along with parsimony and consistency with the prior literature. ${ }^{36}$ To confirm and interpret effect modification, multivariable analyses were stratified by organisational participation.

\section{RESULTS}

\section{Descriptive analysis}

Organisational participation was similar across times (table 1); however, a variation was found in the type of organisation in which farmers participated (data not shown). Increases were observed in the proportion of individuals who participated in commercial potato production organisations (T1 $31 \%$ to T2 35\%) and in other types of organisations ( $13 \%$ to $23 \%$ ), with decreases in conflict-resolution organisations (56\% to $42 \%)$. In the last two categories, this change was statistically significant $(\mathrm{p}<0.001)$.

The mean neurocognitive performance score was 4.4 at T1 (SD 1.4). IPM practices were used by more than $50 \%$ of the individuals at both $\mathrm{T} 1$ and $\mathrm{T} 2$, though the percentage of individuals who did not use these practices increased non-significantly from $39.9 \%$ at $\mathrm{T} 1$ to $44.7 \%$ at T2 $(p>0.1)$. There were no statistically significant changes in the use of Pesticides Ib and II between the two periods $(\mathrm{p}>0.1)$. At $\mathrm{T} 1$, the mean number of years of schooling was 6.1 (SD 2.4), and the mean age was 41 years (SD 13.0; table 1 ).

In the lost-to-follow-up analysis (data are not shown in tables), at T2, 19 individuals ( $8.3 \%$ of the total at T1) were either lost-to-follow-up (14) or excluded for other reasons (5). In this latter group, the percentage of individuals

\section{Table 1 Descriptive characteristics of the study population}

\begin{tabular}{|c|c|c|c|}
\hline Variables & T1 & T2 & p Value \\
\hline \multicolumn{4}{|l|}{ Participation in organisations ( $\mathrm{n}$; \%) } \\
\hline Does not participate & $77(37.0)$ & $76(36.5)$ & \multirow[t]{2}{*}{$(0.91)^{\star}$} \\
\hline Participates & $131(62.9)$ & $132(63.4)$ & \\
\hline Neurocognitive performance index $†$ (mean, SD) & $4.4(1.4)$ & $4.3(1.4)$ & $(0.20) \ddagger$ \\
\hline \multicolumn{4}{|l|}{ Use of IPM practices (n; \%) } \\
\hline No use & $83(39.9)$ & $93(44.7)$ & \multirow{3}{*}{$(0.52) \S$} \\
\hline Little/moderate use & $55(26.4)$ & $55(26.4)$ & \\
\hline Good/very good use & 70 (33.6) & $60(28.8)$ & \\
\hline \multicolumn{4}{|l|}{ Uses pesticides $\mathrm{lb}$ and IIף (n; \%) } \\
\hline $0 \mathrm{~kg} / \mathrm{ha}$ & $52(25.0)$ & $58(27.8)$ & \multirow{5}{*}{$(0.67) \ddagger$} \\
\hline$\leq 1.1 \mathrm{~kg} / \mathrm{ha}$ & $73(35.1)$ & $66(31.7)$ & \\
\hline$>1.1 \mathrm{~kg} / \mathrm{ha}$ & $83(39.0)$ & $84(40.3)$ & \\
\hline Years of schooling ${ }^{\star \star}$ (mean, SD) & $6.1(2.4)$ & $6.3(2.6)$ & \\
\hline Age in years (mean, SD) & $41.7(13.0)$ & $44.2(13.1)$ & \\
\hline \multicolumn{4}{|c|}{ 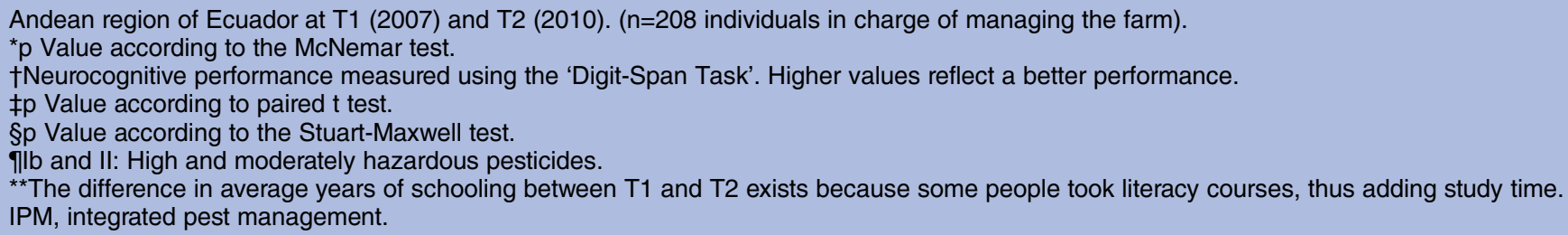 } \\
\hline
\end{tabular}


Table 2 Multivariable linear regression coefficients $†$ (SE) $\ddagger$ for the association between the use of IPM practices and neurocognitive performance ( $n=416$ observations)

\begin{tabular}{|c|c|c|c|c|}
\hline Variables & $\begin{array}{l}\text { Model } \\
\text { A }\end{array}$ & $\begin{array}{l}\text { Model } \\
\text { B }\end{array}$ & $\begin{array}{l}\text { Model } \\
\text { C }\end{array}$ & $\begin{array}{l}\text { Model } \\
\text { D }\end{array}$ \\
\hline Constant§ & $3.98(0.17)^{\star \star \star}$ & $3.97(0.17)^{\star \star \star}$ & $4.81(0.44)^{\star \star \star}$ & $4.89(0.44)^{\star \star \star}$ \\
\hline \multicolumn{5}{|l|}{ Use of IPM (No use $=0$ ) } \\
\hline Little/moderate use & $0.41(0.15)^{\star \star \star}$ & $0.41(0.15)^{\star \star \star}$ & $0.41(0.15)^{\star \star \star}$ & $0.45(0.15)^{\star \star}$ \\
\hline Good/very good use & $0.71(0.29)^{\star \star}$ & $0.70(0.28)^{\star \star}$ & $0.73(0.27)^{\star \star \star}$ & $0.08(0.15)$ \\
\hline \multicolumn{5}{|l|}{ Participation in organisations } \\
\hline Participates (does not participate $=0$ ) & $0.24(0.18)$ & $0.27(0.14)^{\star}$ & $0.26(0.14)^{\star}$ & $0.06(0.13)$ \\
\hline \multicolumn{5}{|l|}{ Uses pesticides $\mathrm{Ib}$ and $I I \eta($ No use $=0)$} \\
\hline$\leq 1.1 \mathrm{~kg} / \mathrm{ha}$ & $0.25(0.15)^{*}$ & $0.25(0.15)^{*}$ & $0.25(0.15)$ & $0.23(0.16)$ \\
\hline$>1.1 \mathrm{~kg} / \mathrm{ha}$ & $0.17(0.23)$ & $0.21(0.17)$ & $0.23(0.15)$ & $0.23(0.16)$ \\
\hline $\begin{array}{l}\text { Product term } 1 \text { (Good/very good use of } \\
\text { IPM } \times \text { Participates in organisations) }\end{array}$ & $-0.88(0.31)^{\star \star \star}$ & $-0.88(0.31)^{\star \star \star}$ & $-0.88(0.31)^{\star \star \star}$ & - \\
\hline $\begin{array}{l}\text { Product term } 2 \text { (Good/very good use of IPM } \times \text { Uses } \\
\text { pesticides } \mathrm{lb} \text { and II >1.1 kg/ha) }\end{array}$ & $0.05(0.26)$ & $0.07(0.25)$ & - & - \\
\hline $\begin{array}{l}\text { Product term } 3 \text { (Uses pesticides }>1.1 \mathrm{~kg} / \mathrm{ha} \times \text { Participates } \\
\text { in organisations) }\end{array}$ & $0.06(0.26)$ & - & - & - \\
\hline Age & $-0.03(0.00)^{\star \star *}$ & $-0.03(0.00)^{\star * \star}$ & $-0.03(0.06)$ & $-0.03(0.00)^{\star \star \star}$ \\
\hline Years of schooling & $0.09(0.03)^{\star \star \star}$ & $0.08(0.03)^{\star \star \star}$ & $0.08(0.03)^{\star * \star}$ & $0.09(0.03)^{\star \star \star}$ \\
\hline Time $(\mathrm{T} 1=0, \mathrm{~T} 2=1)$ & $-0.05(0.10)$ & $-0.05(0.10)$ & $-0.05(0.10)$ & $-0.06(0.10)$ \\
\hline \multicolumn{5}{|c|}{$\begin{array}{l}\text { Criteria of quasi-likelihood: } \mathrm{QIC}_{\mathrm{u}} \text { values: Models } \mathrm{A}, \mathrm{B}, \mathrm{C}=1293 \text {; Model } \mathrm{D}=1305.798 . \\
{ }^{*} \mathrm{p}<0.1,{ }^{* *} p<0.05,{ }^{* * *} p<0.01 \text {. } \\
\text { †Obtained using the generalised estimating equations (GEE) model. } \\
\text { fSE=SD } / \sqrt{n} \text {. } \\
\text { §Constant value obtained with the continuous variables (age and years of schooling) centres at their mean. } \\
\text { ๆllb and II: High and moderately hazardous pesticides. } \\
\text { IPM, integrated pest management. }\end{array}$} \\
\hline
\end{tabular}

$(57.9 \%)$ who did not participate in organisations was significantly higher $(\mathrm{p}<0.1)$, as was the percentage of individuals who did not use IPM practices $(47.5 \%)$. The mean value for neurocognitive performance at $\mathrm{T} 1$ was found to be insignificantly higher (4.8, SD 1.3 , p $>0.1)$. No statistically significant differences between these groups and the final study population were found $(p>0.1)$ with respect to the mean number of years of schooling $(6.4, \mathrm{SD} 2.2)$ or age (44.2, SE 15.6) at T1.

\section{Multivariable analysis}

Results from the multivariate analysis (table 2) showed that for greater implementation of IPM practices (good/very good and slight/medium vs not applicable), the value of the neurocognitive performance index increased significantly $(p<0.05$; models $A, B$ and $C)$. In these models, the magnitude of the coefficient of association was almost twice as high $(\beta=0.71$, SE 0.19$)$ where the application of these practices was good/very good compared to when the application was slight/medium $(\beta=0.41$, SE 0.15$)$, indicating a dose-response relationship. The coefficient of association between the implementation of IPM practices and neurocognitive performance was similar in all three models when people participated in organisations (A: $\beta=0.24 ; \mathrm{B}$ : $\beta=0.27$; and $C: \beta=0.26)$. However, the values were significantly different $(\mathrm{p}<0.1)$ in models $\mathrm{B}$ and $\mathrm{C}$ when the association of the use of pesticides and product terms was adjusted.
In Model D, when the product term Application of good/very good IPM $\times$ Participation in organizations" was removed, the coefficient of association for the implementation of IPM practices good/very good decreased and the association was no longer significant $(\beta=0.08$, SE $0.15)$. Based on ' $\mathrm{QICu}$ ' values and the existing literature, ${ }^{27}{ }^{29}$ model $\mathrm{B}$ was chosen for the stratified analysis according to the presence or absence of participation in organisations. To more closely examine these relationships, we stratified table 1 data on use of IPM by participation in organisations (table 3). With stratification, we can clearly see: that Good/very good use of IPM was more prevalent among those participating in organisations at both times. More interesting still is that little/ moderate use increased and no use remained relatively stable among those participating in organisations. In contrast, little/moderate use decreased among those not participating in organisations and no use increased among those not participating in organisations. We can conclude that organisational participation was associated with improved use of IPM over time, compared to the decline in use among those not in organisations, consistent with the broader context of smallholder agriculture.

Then we estimated coefficients using model B, with adjustment for relevant covariates and incorporating time of measurement (table 4). We can see that the coefficient of association between the implementation of IPM practices for the category good/very good and neurocognitive performance when small farmers were 
Table 3 Use of IPM, stratified by participation in organisations

\begin{tabular}{|c|c|c|c|}
\hline Participation in organisations & Variables & Time 1 & Time 2 \\
\hline \multirow[t]{4}{*}{ Does not participate $(n=153)$} & Use of IPM (n, \%) & & \\
\hline & No use & $39(50.6)$ & $52(68.4)$ \\
\hline & Little/moderate use & $23(30.0)$ & $14(18.4)$ \\
\hline & Good/very good use & $15(19.4)$ & 10 (13.2) \\
\hline \multirow[t]{4}{*}{ Participates $(n=263)$} & Use of IPM (n, \%) & & \\
\hline & No use & $44(33.6)$ & $41(31.1)$ \\
\hline & Little/moderate use & $32(24.4)$ & 41 (31.1) \\
\hline & Good/very good use & $55(42.0)$ & $50(37.8)$ \\
\hline
\end{tabular}

involved in organisations was negative and moderate $(\beta=-0.17$, SE 0.21$)$, but not significant $(p>0.1)$. When farmers did not belong to organisations, the association coefficient for the relationship studied was higher and significant $(\beta=0.79$, SE $0.39, \mathrm{p}<0.05)$.

\section{DISCUSSION}

The findings of this study suggest that organisations as structures of social capital seem to be functional in the social reproduction process of the communities studied. These observations have been reported by other authors, ${ }^{5-13}$ who report that social structures and forms of social capital-such as information and practicesfacilitated by the organisations are conditioned by their social context; therefore, their effects on population health could depend on this social determination. The results also highlight the need to redirect the analysis of social capital to a more integral study of social

Table 4 Adjusted coefficients $\dagger$ of multivariate linear regression ( $\beta) \ddagger(\mathrm{SE})$ for the association between the use of IPM practices and neurocognitive performance, stratified by participation in organisations

\begin{tabular}{|c|c|c|}
\hline \multirow[b]{2}{*}{ Variables } & \multicolumn{2}{|c|}{ Participation in organisations } \\
\hline & $\begin{array}{l}\text { Does not } \\
\text { participate } \\
(n=153)\end{array}$ & $\begin{array}{l}\text { Participates } \\
(n=263)\end{array}$ \\
\hline Constant & $5.07(0.69)^{\star \star \star}$ & $4.98(0.53)^{\star \star \star}$ \\
\hline \multicolumn{3}{|c|}{ Use of IPM (No use=0, $n=176$ ) } \\
\hline $\begin{array}{l}\text { Little/moderate } \\
\text { use }(n=110)\end{array}$ & $0.36(0.26)$ & $0.34(0.19)^{*}$ \\
\hline $\begin{array}{l}\text { Good/very good } \\
\text { use ( } n=130) \text { (vs } \\
\text { no use) }\end{array}$ & $0.79(0.39)^{\star *}$ & $-0.17(0.21)$ \\
\hline
\end{tabular}

Variance explained: $31.4 \%$ for those who did not participate in organisations; and $18 \%$ for those who did participate in organisations.

${ }^{*} \mathrm{p}<0.1,{ }^{* *} \mathrm{p}<0.05,{ }^{* * *} \mathrm{p}<0.01$.

†Adjusted for: use of pesticides lb and II, interaction term 2 (good/ very good use of IPMxuses pesticides $\mathrm{lb}$ andll $>1.1 \mathrm{~kg} / \mathrm{ha}$ ), age, years of schooling, time of measurement.

$\ddagger$ Obtained from the generalised estimating equations (GEE) model.

IPM, integrated pest management. determinants, without considering social capital exclusively as a psychosocial factor with little connection to its context.

Contextualising the findings of the present and prior study $^{2}$ according to the definition provided by Bourdieu, ${ }^{14}$ it is possible to affirm that social capital refers to the actual or potential resources that people access through membership in an institutionalised network of known and recognised relationships. According to that author, what are exchanged through social capital can become material or symbolic profits. The combined results of this study and our prior research ${ }^{2}$ suggest that in the case of small-scale farming communities with high levels of social cohesion, ${ }^{2}$ in which the population is sensitised to the impact of agricultural production processes on human health, organisations can provide resources such as information and practices but they may not reduce health risks. An overemphasis among organisations on production may reduce the positive health impacts associated with Good/ very good application of IPM practices. Prior studies provide some clues to understanding these findings in the context of population livelihoods. ${ }^{23} \quad 27 \quad 29$ Smallholder farming communities often perceive that IPM practices cause crops to become more susceptible to pests, whereas the application of pesticides (particularly those of high toxicity) ensures harvests and reduces production uncertainties. The use of pesticides guarantees the production of larger and apparently healthier products of competitive quality for consumers. A large percentage of farmers (approximately 70\%) in the two studies used pesticides of extreme and moderate toxicity. ${ }^{20}$ Small farmers' concurrent use of IPM practices and pesticides of various toxicity levels have been observed in other studies. ${ }^{23} 2737$ The results of this study suggest that the implementation of IPM crop management practices may be different among those participating in organisations but not with a differential effect on the health of small-scale farmers.

On the other hand, other aspects of social capital are important for farmer human capital, including their health. In prior work, we have shown that community deprivation remained an important independent, negative determinant of neurobehavioural function (29), a 
form of human capital. Years of education have been positively associated with changes in knowledge about pesticide hazards (27) and farmer neurobehavioural function (29-31), both forms of human capital. However, across studies of pesticide effects on health, ongoing exposure to high toxicity pesticides has a cumulative negative impact on neurobehavioural function, thus decreasing human capital. Hence, organisations as social structures which can facilitate appropriate information and less risky practices in crop management can thus contribute to the development and maintenance of human capital in multiple ways.

\section{Study limitations}

The findings of this study are explanatory rather than predictive for understanding the structures through which social capital is facilitated in contexts of development at micro levels (organisational and community). The primary limitation of this study was that the exploration of the aspects of social capital related to health impacts in the process of smallholder agriculture was not the primary goal of the previous participatory research (EcoSalud II). ${ }^{27}{ }^{28}$ The results of this study should be considered within the context of social production of health ${ }^{38}$ and especially as an input to the debate on the role of social capital in relation to the health of individuals, groups and populations who live in contexts of social inequity.

Our indicators of social capital were focused on organisational participation, although we recognise that this is just one component. It would have been beneficial to gather information about the duration of participants' participation in organisations, to complement our findings. Similarly, the reasons that people participated in organisations would have been useful to further the understanding of the functionality of these structures as channels for accessing potential resources (such as information or practices). Despite these limitations, previous studies of similar populations ${ }^{2} 2326-2937$ enabled the understanding and interpretation of the results using pre-existing knowledge.

Restrictions in sample size did not allow an analysis of the relationship between the type of organisation to which the subjects belonged and the impact of those organisations on health. However, previous studies ${ }^{4} 91839$ indicate that in highly cohesive communities, practices influence and can be influenced by practices within social structures as organisations. In communities similar to the population studied (ie, communities with similar livelihoods and production processes), we hypothesise that the information and practices provided by organisations correspond to the process of social reproduction, regardless of their attributes (such as the activity on which these structures are focalised).

This study's emphasis on understanding organisations' functionality as social structures to facilitate and maintain information and practices to reduce the health impacts of crop management justified the selection of the population studied, given that only the communities that showed a better response to the project-based interventions (EcoSalud II) were included. ${ }^{27}$ These communities had resources that could potentially be maintained and/or transmitted over time.

Finally, the fact that a higher percentage of lost-to-follow-up was observed in the population that did not belong to organisations may have contributed to a selection bias. However, migration was one of the primary reasons for the loss observed, similar to the social vulnerability of people who do not belong to organisations in other social contexts. The lack of links to other people could limit access to other types of social, symbolic and economic capital and to resources needed to survive, thus placing the population in a state of impoverishment. This emphasises the role of organisations in microlevel contexts of development. It is therefore important to understand what these structures promote, transmit and maintain, as well as their potential impacts on a population's health and well-being.

\section{CONCLUSIONS}

In micro level community contexts with shared livelihood and common production processes, such as in small-scale agriculture, organizational participation may result in the differential adoption of crop management practices with differential effects on farmers' health.

Contributors FO was in charge of collecting the data. She performed the analysis and wrote the research report, developing the research as part of her dissertation. EM participated in orienting the analysis process. He discussed the research findings and reviewed the research results, conclusions and final research report. DCC participated in the processes of collecting data, performing the analysis and writing the final research report. He was a comentor in FO's doctoral training process.

Funding Data collection was funded by the International Development Research Centre (IDRC) under two project grants: EcoHealth Program \#101810-001 and Global Health Leadership Award \#103460-068. Personnel support was provided for the lead author's doctoral studies by the CAPES (Higher Education Training Coordination) program of the Government of Brazil.

\section{Competing interests None.}

Patient consent Obtained.

Ethics approval Bioethics Committee of the Ecuador National Health Council (T1) and the Internal Review Board of the Institute of Collective Health, Federal University of Bahia, Brazil.

Provenance and peer review Not commissioned; externally peer reviewed. Data sharing statement No additional data are available.

Open Access This is an Open Access article distributed in accordance with the Creative Commons Attribution Non Commercial (CC BY-NC 3.0) license, which permits others to distribute, remix, adapt, build upon this work noncommercially, and license their derivative works on different terms, provided the original work is properly cited and the use is non-commercial. See: http:// creativecommons.org/licenses/by-nc/3.0/

\section{REFERENCES}

1. Kawachi I, Berkman L. Social cohesion, social capital, and health. In: Berkman L, Kawachi I, eds. Social epidemiology. New York: Oxford University Press, 2000:174-90. 
2. Orozco F, Mota E, Cole D. Capital Social e Información para la Salud en el contexto del modo de vida de agricultores de pequeña escala. [Social Capital and Information for Health in the context of the livelihood of smallholder farmers] 2014. (Submitted to Salud Colectiva).

3. Coleman J. Social capital in the creation of human capital. In: Dasgupta P, Serageldin I, eds. Social capital a multifaceted perspective. Washington DC: The World Bank, 1988:13-39.

4. Woolcock M. Social capital and economic development: toward a theoretical synthesis and policy framework. Theor Soc 1998;27:151-208

5. Muntaner C, Lynch J, Davey G. Social capital and the third way in public health. Crit Public Health 2000;10:107-24.

6. Muntaner C, Lynch J, Hillemeier M, et al. Economic inequality, working-class power, social capital, and cause-specific mortality in wealthy countries. Int J Health Serv 2002;32:629-56.

7. Navarro V. A critique of social capital. Int $J$ Health Serv 2002;32:423-32.

8. Edmondson R. Social capital: a strategy for enhancing health? Soc Sci Med 2003;57:1723-33.

9. Carpiano RM. Neighborhood social capital and adult health: an empirical test of a Bourdieu-based model. Health Place 2007:13:639-55.

10. Poortinga W. Community resilience and health: the role of bonding, bridging, and linking aspects of social capital. Health Place 2012:18:286-95.

11. Stephens C. Social capital in its place: using social theory to understand social capital and inequalities in health. Soc Sci Med 2008;66:1174-84.

12. Lin N. Inequality in social capital. Contemp Sociol 2000;29:785-93.

13. Szreter S, Woolcock M. Health by association? Social capital, social theory, and the political economy of public health. Int $J$ Epidemiol 2004;33:650-67.

14. Bourdieu P. The forms of capital. In: Richardson JG, ed. Handbook of theory and research for the sociology of education. New York: Greenwood Press, 1986:13-39.

15. Kawachi I, Kennedy B, Glass R. Social capital and self-rated health: a contextual analysis. Am J Public Health 1999;89:1187-92.

16. Fujiwara T, Kawachi I. A prospective study of individual-level social capital and major depression in the United States. J Epidemiol Community Health 2008;62:627-33.

17. Ziersch A, Baum F, MacDougall C, et al. Neighbourhood life and social capital: the implications for health. Soc Sci Med 2005;60:71-86.

18. Byrne A, Edmondson R, Varley T. Arensberg and Kimball and anthropological research in Ireland: introduction to the third edition. In: Arensberg C, Kimball S. eds. Family and Community in Ireland. Ireland: CLASP, 2001:1-101.

19. Chiriboga M. Desafíos de la pequeña agricultura familiar frente a la globalización [Challenges of small family farms facing globalization] In: Martínez L, ed. El Desarrollo Sostenible en el Medio Rural [Sustainable Development in Rural Areas]. Quito: FLACSO-Sede Ecuador, 1997:9-24.

20. World Health Organization (WHO). The WHO recommended classification of pesticide by hazard and guidelines to classification 2009. Geneva: WHO, 2010.

21. Nieto C. ¿Puede un agricultor ecuatoriano acceder al salario digno?: factores de su realidad social y financiera que lo limitarían. [Do Ecuadorian farmers earn a decent living wage? Social reality and economic limiting factors] Fundación Desde el Surco 2011. http://www. desdeelsurco.com/index.php?option=com_content\&view=article\&id=61: salario-digno\&catid=1:latest-news\&ltemid=50 (accessed 20 Aug 2011).
22. Bravo AL. Análisis de las políticas agrícolas aplicadas en el Ecuador en los noventas desde la perspectiva de la soberanía alimentaria [Analysis of agricultural policies in Ecuador in the nineties from the perspective of food sovereignty] (Master's thesis). Quito: Facultad Latinoamericana de Ciencias Sociales sede Ecuador, 2008.

23. Orozco F, Cole DC, Forbes G, et al. Monitoring adherence to the international code of conduct: highly hazardous pesticides in central Andean agriculture and farmer's rights to health. Int J Occup Environ Health 2009;15:255-69.

24. Marx K. O Capital. Crítica da Economia Política. 27th ed. Volume I. Rio de Janeiro: Civilação Brasileira, 2010.

25. Food and Agriculture Organization of the United Nations (FAO). Código Internacional de Conducta para la Utilización y Distribución de Pesticidas [Organization of the United Nations Food and Agriculture Organization (FAO). International Code of Conduct on the Distribution and Use of Pesticides]. Rome: FAO, 2003.

26. Mancini F, Jiggins JL, O'Malley M. Reducing the incidence of acute pesticide poisoning by educating farmers on integrated pest management in South India. Int J Occup Environ Health 2009;15:143-51.

27. Orozco FA, Cole DC, Ibrahim S, et al. Health promotion outcomes associated with a community-based program to reduce pesticide-related risks among small farm households. Health Promot Int 2011;26:432-46.

28. Orozco F, Cole DC. Tackling challenges to farmers' health and agro-ecosystem sustainability in highland Ecuador. In: Charron D, ed. Ecohealth research in practice innovative applications of an ecosystem approach to health. Ottawa, Canada: Springer, 2012:47-58.

29. Cole DC, Orozco FA, Ibrahim S, et al. Community and household socioeconomic factors associated with pesticide-using, small farm household members' health: a multi-level, longitudinal analysis. Int $J$ Equity Health 2011;10:54.

30. Anger WK. Neurobehavioural tests and systems to assess neurotoxic exposures in the workplace and community. Occup Environ Med 2003;60:531-8, 474.

31. Rohlman DS, Lasarev M, Anger WK, et al. Neurobehavioral performance of adult and adolescent agricultural workers Neurotoxicology 2007;28:374-80.

32. Twisk JW. Applied longitudinal data analysis for epidemiology: a practical guide. Cambridge: Cambridge University Press, 2003.

33. Cui J. QIC program and model selection in GEE analyses. Stata $J$ 2007;7:209-20.

34. Szkclo M, Nieto FJ. Epidemiology: Beyond the Basics. Sudbury: Jones and Bartlett Publishers Inc., 2004.

35. Kleinbaum DG, Kupper LL, Morgenstern H. Epidemiology research. Principles and quantitative methods. New York: Van Nostrand Reinhold, 1982.

36. Catavassi R, Gonzales $\mathrm{M}$, Winters $\mathrm{P}$, et al. Linking smallholders to the new agriculture economy: an evaluation of the Plataformas Program in Ecuador (ESA Working Paper No. 09-06). Rome: Agricultural Development Economic Division, Food and Agriculture Organizations of the United Nations, 2009.

37. Cole DC, Sherwood S, Paredes M, et al. Reducing pesticide exposure and associated neurotoxic burden in an Ecuadorian small farm population. Int J Occup Environ Health 2007;13:281-9.

38. Laurell AC, Noriega M. Processo de Produção e Saúde: Trabahlo y Desgaste Operario. São Paulo: Editorial Huitec, 1989.

39. Grootaert C. Social capital: the missing link? Social capital initiative. Washington, DC: The World Bank Social Development Family Environmentally and Socially Sustainable Development Network, the World Bank, 1998. 